\title{
KAEDAH PINTAR MURAJAAH AL-QUR'AN: KAJIAN DI INSTITUSI PENGAJIAN TAHFIZ MALAYSIA
}

\author{
Nor Hafizi Yusof \\ Universiti Sultan Zainal Abidin, Malaysia
}

\begin{abstract}
Abstrak: Sistem pengajian Tahfiz al-Quran mula mendapat tempat dalam kalangan ibu bapa dan pelajar sendiri. Berdasarkan perkembangan ini, pihak kerajaan, swasta mahupun persendirian telah mengorak langkah dengan memperkenalkan sistem tahfiz integrasi di samping pengajian tahfiz agama atau pondok yang telah sedia ada. Sistem pengajian yang dijalankan secara serentak ini memerlukan persediaan mental dan ketahanan fizikal daripada para pelajar. Ia juga memerlukan panduan yang berkesan dan perancangan yang sistematik bagi memastikan cita-cita melahirkan para cendekiawan huffaz yang thabit hafazannya tercapai bukan sekadar gelaran al-hafiz semata-mata tetapi hakikatnya mereka tidak mengingati ayatayat yang telah dihafaz sebagaimana yang berlaku di kebanyakan institusi tahfiz integrasi sekarang. Kajian ini bertujuan mengenal pasti gaya hidup pelajar tahfiz al-Quran integrasi yang menjadi faktor kepada berjaya atau gagalnya mereka dalam menghafaz dan mengekalkan hafazan mereka. Ia juga bertujuan bagi merangka satu modul dan panduan kepada pelajar tahfiz integrasi supaya dapat lahir sebagai para huffaz yang mampu menjaga hafazan mereka dengan baik berdasarkan kesedaran dan sistem murajaah yang berkesan. Data akan dikumpulkan melalui borang soal selidik pelajar dan temuramah dengan pakar dalam bidang ini dan seterusnya kan di analisis dan dirumuskan sebagai modul tersendiri sebagai pandual pelajar. Jangkaan awal dapatan kajian mendapati kelemahan pelajar dalam memastikan mereka menghafaz dan menjaga hafazan dengan baik ialah kekangan masa dan jadual yang padat,kurangnya motivasi dan tiada sistem murajaah yang berkesan. Modul ini menerapkan satu model murajaah berkesan yang berkonsepkan empat kunci utama yaitu kesedaran, kesungguhan, istiqomah, kesabaran) Justeru modul yang dirangka akan menjadi panduan kepada pelajar bagi memastikan mereka lahir sebagai al-hafiz yang penuh bermotivasi dan konsisten dalam menjaga hafazan al-Quran.
\end{abstract}

Kata Kunci: Murajaah; Tahfiz; Intrgrasi; Modul; Ulul albab 


\section{PENDAHULUAN}

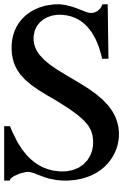

istem

pengajian berteraskan hafazan al-Quran bukanlah suatu perkara baru, malah ianya telah bermula sejak zaman Rasulullah SAW dan menjadi tradisi ilmu yang diwarisi kepada para sahabat, tabiin seterusnya para ulama hingga kini. Secara Tradisinya pengajian tahfiz lebih tertumpu pada sistem tradisional atau pondok berpandukan sistem tahfiz yang diwarisi oleh guru-guru lepasan Arab Saudi, Mesir, Yaman, Pakistan, India dan beberapa negara di Asia Tenggara seperti Indonesia.

Polisi kerajaan yang menjadikan kelulusan akademik seperti SPM sebagai syarat untuk berkhidmat dalam kerajaan, telah memberi kesedaran kepada ibu bapa untuk menyediakan dan mendorong anakanak mereka untuk menghantar anak-anak mereka ke pusat-pusat tahfiz yang menyediakan pemeriksaan awam. Oleh kerana permintaan yang tinggi dari kesedaran ibu bapa di seluruh negara yang ingin melihat anak-anak mereka menjadi seorang hafiz dan dalam masa yang sama berjaya juga dalam bidang akademik menyebabkan banyak pusat-pusat tahfiz diwujudkan sama ada oleh pihak kerajaan, swasta atau persendirian.

Dalam konteks Malaysia hari ini, pusatpusat tahfiz yang dibina sama ada oleh pihak kerajaan atau pun pihak swasta serta persendirian mempunyai aliran pengajian yaitu aliran tahfiz agama/pondok sepenuhnya dan tahfiz akademik (integrasi). Aliran tahfiz agama/pondok merupakan sistem pengajian pada peringkat awal dan ianya diamalkan hingga sekarang seperti di kebanyakan institusi tahfiz setiap negeri di bawah kelolaan JAKIM dan juga swasta seperti kebanyakan tahfiz pondok. Sistem Tahfiz Integrasi pula timbul sebagai satu pembaharuan dalam sistem pengajian Tahfiz. Ia diasaskan berdasarkan minat dan permintaan yang tinggi dari pelajar dan ibu bapa terhadap hafalan al-Quran. Mereka berpendapat hafiz al-Quran perlu diperluaskan dalam pelbagai profesion bukannya tertumpu kepada pengajian agama sahaja atau menjadi ustaz sahaja.

Apa pun aliran tahfiz yang dilalui oleh pelajar, tanggung jawab utama mereka ialah menghafaz al-Quran serta menjaga hafazan tersebut daripada lupa. Justeru, aliran tahfiz integrasi dilihat mempunyai cabaran yang besar dalam mencapai matlamat ini. Hal ini kerana kekangan masa serta terpaksa mempelajari subjek-subjek akademik seeiring dengan hafalan al-Quran setiap hari. Yang terpenting dalam menghafal adalah bagaimana kita meningkatkan kelancaran (menjaga) atau melestarikan hafalan tersebut sehingga Al-Qur'an tetap ada dalam dada kita. Untuk melestarikan hafalan diperlukan kemahuan yang kuat dan istiqamah yang tinggi. Dia harus meluangkan waktunya 
setiap hari untuk mengulangi hafalannya. (Anisa Ida Khusniyah, 2014, 29-30)

Kajian ini dilakukan berdasarkan kepada perkembangan semasa dalam negara mengenai corak permintaan yang tinggi dari tahun ke tahun untuk memasuki institusi tahfiz integrasi yang menawarkan sijil tahfiz dan sijil akademik peperiksaan awam seperti Penilaian Menengah Rendah (PMR) atau Penilaian Tingkatan 3 (T3), Sijil Pelajaran Malaysia (SPM) dan Sijil Tinggi Persekolahan Malaysia (STPM).

Penubuhan Pusat Tahfiz al-Quran di seluruh negara telah memainkan peranan besar dalam perkembangan pengajian ilmuilmu al-Quran terutamanya dalam bidang Hafazan dan Qiraat. Namun kebanyakkan pusat-pusat tahfiz yang ditubuhkan ini hanya al-Quran dan subjek agama sahaja dengan meminggirkan ilmu akademik yang menjadi tunjang dalam sistem pendidikan negara. Keadaan ini berterusan begitu lama sehinggalah pada akhir 80an dan awal 90an wujud kesedaran oleh pihak pengelola atas desakan masyarakat dan ibu bapa untuk menyediakan pusat pengajian yang menyediakan ilmu al-Quran dan ilmu akademik seiring (Syed Ahmad Tarmizi bin Syed Omar, 2013, 14.)

Kesedaran peri pentingnya ilmu alQuran dan ilmu akademik diadunkan secara bersepadu maka tradisi penubuhan pusat tahfiz telah mengalami perubahan mengikut masa dan zaman. Dari hanya berfokuskan kepada kebolehan menghafaz dan mendalami ilmu yang berkaitan dengan alQuran semata-mata kepada pengembangan disiplin ilmu yang lebih padu dan meyeluruh merangkumi segenap ilmu yang wujud dalam wahyu untuk faedah dunia dan akhirat. Atas kesedaran bahawa betapa dunia hari ini memerlukan para huffaz yang profesional untuk menerajui dunia, maka wujud pusat tahfiz yang mengadunkan ilmu al-Quran dan ilmu akademik secara bersepadu antaranya Ma'ahad Tahfiz alQuran al-Itqan, Selangor, Ma'ahad Tahfiz al-Quran wal Qiraat, Pulau Chondong, Kelantan dan di negeri Sekolah IMTIAZ Terengganu dan MRSM Ulul Albab. Kombinasi dua sistem kurikulum yang berjalan serentak ini dianggap sebagai inovasi dalam pendidikan Negara (Syukeri Mohamed, 2010).

Pelaksanaan pembelajaran secara serentak dalam sistem tahfiz integrasi merupakan suatu beban kepada pelajar dan dilihat menyalahi displin pengajian turath dan amalan para ulama terdahulu. Hal ini kerana displin pengajian al-Quran para ulama silam ialah mereka memulakan dengan pengajian dan hafazan al-Quran sebelum mendalami ilmu-ilmu lain. Perkara ini telah direkodkan dalam kitab-kitab sirah dan tarjuman bahawa majoriti para ulama yang masyhur dalam dunia Islam telah 
menghafaz al-quran seawal usia 7-10 tahun sehingga membolehkan mereka menumpukan sepenuhnya kepada hafazan dan murajaah al-Quran. Umpamanya Imam Syafi'i) (K.H Sirajuddun Abbas 1979, 13) dan Imam At-Thabari (Muhammad Hussin al-Zahabiy, 2000, j.1,215) Ibnu Khaldun , Ibnu Qudamah dan ( $541 \mathrm{H}-620$ ketika usia 10 tahun, Ibnu Sina ( 370 H- 428 H), ketika umur 5 tahun, Imam Nawawi sebelum baligh, Imam Ahmad bin Hanbal mengafal Al-Quran sejak kecil, Imam As-Suyuthi (w: $911 \mathrm{H})$, menghafal Al-Qur'an sebelum umur 8 tahun, dan Ibnu Hajar Al-Atsqalani (w: $852 \mathrm{H})$ hafal Al-Qur'an ketika berusia 9 tahun.

Justeru sistem integrasi yang dianggap baru dan mencabar ini sudah tentu memerlukan suatu kaedah pelaksanaan yang sistematik dan berkesan bagi memastikan pelaksanaannya mencapai hasil dan kualiti yang maksimum bukannya sekadar gah pada nama sahaja . Secara praktikalnya pengajian tahfiz integrasi menggabungkan subjek hafazan al-Quran dan beberapa subjek yang berkaitan dengan al-Quran dengan subjek akademik sama ada peringkat PT3 atau SPM. Penggabungan ini sudah semestinya akan menambah beban pembelajaran kepada pelajar dalam suatu masa sama ada dari segi bilangan subjek, jumlah jam pembelajaran secara rasmi dan dan pembelajaran tidak rasmi yang meliputi hafazan dan murajaah
al-Quran, waktu ulang kaji akademik serta program-program kurikulum dan kokurikulum yang pelbagai yang dijalankan di sekolah.

Hasil pemerhatian masalah utama yang dihadapi oleh pelajar ialah mempunyai tidak kesedaran, displin masa dan kaedah yang konsisten untuk murajaah al-Quran. Hal ini kerana hafazan dan murajaah al-Quran memerlukan peruntukan masa yang banyak bagi memastikan mereka dapat menghafaz dengan baik seterusnya mengekalkan hafazan tersebut. Secara praktikalnya, menghafaz lebih mudah daripada menjaganya karena orang yang mengahafal didorong oleh semangat untuk menghafaz dan mengingatinya sedangkan menjaga atau mengulang hafalan selalunya diiringi oleh sifat malas. Solusinya, para huffaz harus membuat jadual khusus secara harian untuk mengulang hafalannya. (Anisa Ida Khusniyah, 2014, 67) Sedangkan di institusi tahfiz integrasi kebanyakkan jadualnya adalah sangat padat dari pagi hingga ke petang dan pelajar terpaksa melaksanakan pelbagai projek dan mengikuti pelbagai aktiviti yang disediakan oleh pihak sekolah. Hasil dari situasi ini beberapa persoalan dan permasalahan telah muncul yaitu: Apakah kaedah dalam tahfiz al-Quran yang mempengaruhi tahap thabitnya hafazan pelajar?, Apakah permasalahan yang pempengaruhi konsistensi pelajar dalam 
murajaah al-Quran?, Apakah panduan terbaik sebagai cadangan bagi memastikan pelajar ini thabit hafazannya disamping kecemerlangan akademik?

Kajian ini merupakan satu sumbangan dalam bidang Tahfiz al-Quran. Hal ini kerana kebanyakan panduan yang terdapat dalam pasaran sekarang ialah bagaimana cara menghafaz al-Quran dan tidak dijumpai lagi satu modul khusus dirangka tentang cara penjagaan atau murajaah al-Quran. Sedangkan masalah utama pelajar bidang tahfiz ialah bagaimana mengekalkan hafazan al-Quran bukannya bagaimana cara menghafaz. Justeru, kajian ini akan menjadi panduan kepada pelajar bidang tahfiz terutamanaya tahfiz integrasi yang menggabungkan tahfiz dan akademik dalam satu masa. Panduan ini dirangkan berdasarkan analisis kekuatan dan kelemahan pelajar dalam bidang serta mengambil kira beberapa pendapat serta pengalaman pakar dalam bidang Tahfiz alQuran. Modul ini sebagai cadangan untuk diguna pakai sebagai panduan di sekolahsekolah menengah kementerian aliran Tahfiz, Imtiaz dan MRSM Ulul Albab dan lain-lain institusi yang sealiran dengannya.

\section{METODOLOGI}

Kajian ini berbentuk mod-campuran (Mix method) yang menggabungkan kaedah kualitatif dan kuantitatif yang bertujuan untuk mengenal pasti tahap penguasaan hafazan al-Quran pelajar sekolah tahfiz integrasi berdasarkan amalan harian mereka seterusnya merangka satu modul terbaik bagi mengatasi masalah ini. Bagi kaedah kualitatif kajian dijalankan berdasarkan kaedah penyelidikan kajian perpustakaan (library research) dan analisis dokumendokumen yang terpilih. Metode ini diimplimentasikan untuk mencapai objektif pertama dan kedua yang akan menganalisis data yang diambil daripada karangankarangan sarjana Islam berkaitan dengan kaedah pembelajaran al-Quran dan penjagaannya . Analisis yang digunakan dalam mencapai objektif ini ialah analisis dokumen.

Analisis kandungan adalah salah satu kaedah analisis yang dijalankan terhadap penyelidikan berbentuk kajian kualitatif (Neuendorf,2002, 1; Schreier, 2012, 1). Analisis ini digunakan untuk meneliti dan menjelaskan tafsiran yang terdapat dalam dokumen. Analisis kandungan merupakan satu teknik penyelidikan dengan membuat kesimpulan secara sistematik dan objektif melalui data berbentuk dokumen (Rohana Yusof, 2004, 34; Krippendorff, 2004, 18). Sabitha Marican $(2005,170)$ dan Othman Lebar (2009, 146) mendefinisikan analisis kandungan sebagai satu penjelasan yang 
meneliti secara sistematik tentang sesuatu kandungan tersurat berbentuk teks.

Bagi kajian berbentuk kuantitatif pula, kajian ini memilih tiga kaedah yaitu kaedah tinjuan (survey), temubual dan kaedah eksperimental. Kajian tinjuan dilaksanakan untuk mendapatkan input yang berguna terutama dalam pembinaan modul murajaah ulul albab. Melalui kaedah data-data berkenaan masalah, serta keperluan pelajar dalam murajaah akan dikumpulkan. kaedah temubual terhadap tokoh-tokoh al-Hafiz dimalaysia juga akan dilakukan bagi mendapatkan input terbaik dalam merangka modul murajaah ulul albab. Data daripada tinjuan dan temubual ini akan digabungkan dan dijadikan asas dalam pembinaan model murajaah ulul albab berdasarkan empat kunci utama yaitu Kesedaran, kesungguhan, istiqomah dan kesabaran

\section{HASIL DAN PEMBAHASAN}

Kajian yang bakal dijalankan ialah khusus berkaitan kaedah terbaik dalam sistem murajaah atau penjagaan hafazan alQuran. Hasil daripada pembacaan dan kajian yang telah dibuat, belum didapati manamana individu atau pengkaji yang menerbitkan bukau atau kajian ilmiyyah khusus pada kaedah murajaan al-Quran kecuali tajuk-tajuk kecil yang dimuatkan dalam kajian mereka berkaitan jaedah hafazan al-Quran. Antara kajian yang telah dijalankan berkaitan tajuk ini ialah:

Anisa Ida Khusniyah. (2014) Menghafal Al-Qur'an Dengan Metode Muraja'ah Studi Kasus Di Rumah Tahfidz Al-Ikhlash Karangrejo Tulungagung. Tesis. Fakultas Tarbiyah Dan Ilmu Keguruan, Institut Agama Islam Negeri (IAIN) Tulungagung. Indonesia. Kajian ini dijalankan di Indonesia. ia melakukan kajian dan pemerhatian terhadap sistem hafazan al-Quran dan penjagaannya melalui kaedah murajaah. kajian dilakukan di Di Pusat Tahfidz AlIkhlash Karangrejo Tulungagung. kajian dijalankan bagi mendapatkan hasil tahfiz menggunakan kaedah murajaah yang dianggap satu-satunya cara yang paling berkesan dalam menghafaz dan menjaga hafalan al-Quran. kajian ini dijalankan dalam bentuk kajian lapangan dan tidak dilakukan modul sebagaimana kajian ini dan ianya diimplimentasikan di Indonesia berbeza degan kajian ini dimana fokusnya ialah di Malaysia.

Mohd Fazri Ahmad Murad. (1999). Metode-Metode Penghafalan al-Quran : Kajian Khusus di Maahad Tahfiz al-Quran Wal Qiraat Negeri Sembilan, Maahad

Ahmadi, Gemenceh, Negeri Sembilan. Universiti Malaya: Latihan Ilmiah Ijazah Sarjana Muda. Kajian ini dilakukan khusus terhadap kaedah-kaedah hafazan al-Quran dengan memfokuskan kajiannya diMahad 
tahfiz negeri Sembilan. tiada dibincangkan tentang kaedah murajaah secara khsus di dalam kajiannya.

Sistem Pembelajaran Dan Kaedah Hafazan Al-Qur'an Yang Efektif: Satu Kajian Di Kuala Lumpur Dan Terengganu oleh Ustaz Abdul Hafiz Bin Haji Abdullah.2005 UTM Kajian ini juga memfokuskan kaedah-kaedah yang digunakan dakam pembelajaran dan Hafazan al-Quran dengan menganalisa beberapa sistem yang telah diguna pakai di instituis pengajian tahfiz di Negara ini dengan memfokuskan beberapa pusat pengajian tahfiz di Kuala lumpur dan Terengganu.

Badarudin Taroji. (1998). Tahfiz AlQuran Di Malaysia: Satu Tinjauan Mengenai Sistem Pentadbiran Dan Sistem Pembelajarannya, Tinjauan Khusus Di Lembah Klang. Bahagian Pengajian Syariah, Akademi Pengajian Islam, UM, KL: Latihan Ilmiah Ijazah Sarjana Muda. Kajian Badaruddin Taroji lebih memfokuskan pelaksanaan sistem pengajian Tahfiz dan kaedah pembelajarannya. Kajian dilakukan di sekolah-sekolah sekitar daerah lembah Klang tanpa memfokuskan kaedah murajaah sebagaimana yang dilakukan pada kajian ini.

Selain itu terdapat juga beberapa penulisan lain yang berkaitan sistem pembelajaran dan hafazan al-Quran tanpa memfokuskan kaedah murajaah seperi Fadhilat Membaca Dan Menghafal alQu'ran Serta Panduan Menghafalnya oleh Ismail Masyhuri al-Hafiz. (1993). Kuala Lumpur: Syarikat Nurul Has,. Panduan Bagi Hafiz-Hafizah \& Qari-Qari'ah oleh Abu Najihat al-Hafiz. (2001) Selangor: Penerbitan Darul Iman Sdn. Bhd, Sejarah \& Kaedah Pendidikan al-Qur'an oleh Mohd Yusof Ahmad. (2000). Kuala Lumpur: Penerbit UM, Pengajian Tahfiz al-Quran: Satu Kajian di Ma'ahad Tahfiz al-Quran Wal Qiraat, Pulau Pinang. Abdul Mutalib bin Hussain. (2003). Fakulti Usuluddin Akademi Islam UM KL: Latihan Ilmiah Ijazah Sarjana Muda. Penghafalan al-Quran Di kalangan Wanita: Satu Kajian di Maahad Tahfiz, Pusat Islam oleh Fauziah Mohd Noor. (1993). Fakulti Usuluddin Akademi Islam UM KL: Latihan Imiah Ijazah Sarjana Muda.

Majoriti kajian di atas hanya berkisar tentang persediaan seseorang pelajar untuk menghafaz al-Quran, motivasi atau kelebihan-kelebihan menghafaz al-Quran, serta kaedah yang digunakan oleh sesuatu institusi tahfiz al-Quran berdasarkan hasil soal selidik yang diedarkan kepada pelajar atau temu bual individu-individu yang berkaitan. Ia juga secara khususnya tertumpu kepada kedah hafazan yang diamalkan oleh sesuatu institusi atau induvidu tanpa memberikan penekanan 
khusus kepada kaedah murajaah atau cara penjagaan hafazan. Justeru kajian ini agak terbeza dengan kajian-kajian terdahulu di mana fokusnya ialah kaedah murajaah yang melibatkan sistem pengurusan jadual kehidupan seharian yang menjadi permasalahan utama bagi pelajar tahfiz alQuran terutamanya pelajar tahfiz integrasi.v Berdasarkan kajian rintis terhadap dua halaqah al-Quran (18 pelajar) di Sekolah Imtiaz Kuala Terengganu dan SMA Khairiah Kuala Terengganu menunjukkan secara umumnya kebanyakan para pelajar tahfiz integrasi tidak dapat menguasai hafazan al-Quran kerana kekangankekangan subjek pembelajaran yang banyak dan jadual yang padat dan Tidak mampu membahagikan masa antara al-Quran dan aktiviti akademik lain dengan masingmasing (83\%),. Dapatan awal juga menunjukkan bahawa para pelajar bermotivasi dlam murajaah al-Quran (44\%) mempunyai teknik dan jadual khusus untuk murajah al-Quran (66\%). Namun teknik dan jadual ini tidak dapat diikuti sepenuhnya kerana kekangan yang dinayatakan tadi yaitu kekangan masa dan tidak mampu membahagikan masa antara al-quran dan ativiti lain. Perkara ini dapat dilihat apabila majority pelajar mengaku bahawa mereka hanya mampu murajaah al-Quran hanya sejuzuk sehari. Paling banyak beberapa pelajar mampu mengulang hanya 2 juzuk sehari. Ia merupakan suatu jumlah yang tidak memadai bagi para huffaz yang sedang berada dalam tempoh pengajian.

Dari segi teknik murajaah majori pelajar berada pada tahap jarang pada perkara berikut:

a. Tasmik murajaah dengan kawan-kawan

b. Main tebuk-tebuk al-Quran

c. Menetapkan waktu khusus untuk mengulang

d. Mengulang melebihi 3 kali hafazan baru selepas tasmik dengan guru dalam sehari

e. Murajaah melalui pendengaran seperti mp4 atau You Tube

Justeru panduan murajaah akan dibangunkan berdasarkan permasalahan utama pelajar yaitu faktor kekangan masa dan kemampuan dan strategi mengatur jadual antara murajaah al-quran dan aktivitiaktiviti lain. Panduan yang berkonsepkan empat kunci utama yaitu kesedaran, kesungguhan, istiqomah dan kesabaran juga akan menekankan aspek teknik murajaah yang menjadi kelemahan dalam kalangan pelajar terutamanya pemantapan hafazan sebelum tasmik dan pengukuhan hafazan baru selepas tasmik. 


\section{SIMPULAN}

Sistem hafazan al-Quran secara integrasi merupakan cabaran bagi para pelajar dan pengurusan tahfiz al-Quran yang perlu diuruskan dengan teliti dan bijaksana. Perkara ini perlu bagi melahirkan al-Hafiz dan professional yang benar-benar menguasai hafazan al-Quran bukannya sekadar khatam tasmik dengan guru tetapi tidak menguasai hafazan tersebut secara keseluruhan. Bagi membangunkan panduan ini perlukan dikenal pasti permasalahan dan kekangan serta aspek kelemahan pelajar. Ia juga perlu diberi keutamaan kepada kurikulum hafazan berbanding mata pelajaran lain terutamanya pada peringkat awal pengajian.

\section{DAFTAR RUJUKAN}

Syukeri Mohamed (2010). Inovasi Kurikulum Sekolah Menengah: Kes Sekolah Imtiaz. UMT: Terengganu.

Abdul Hafiz bin Haji Abdullah (2005). Laporan Penyelidikan: Sistem Pembelajaran dan Kaedah Hafalan al-Quran Yang Efektif: Satu Kajian di Kuala Lumpur dan Terengganu, Universiti Teknologi Malaysia Skudai.

Abdul Mutalib Hussain (2003). Pengajian

Tahfiz al-Quran: Satu Kajian Di Ma'ahad Tahfiz al-Quran Wal Qiraat, Pulau Pinang” Latihan ilmiah Sarjana
Muda, Akademik Pengajian Islam, Universiti Malaya.

Ahmad Dasuki Hashim (2002). “Perbezaan Maahad Tahfiz Swasta dan Kerajaan: Suatu Kajian di Institut al-Quran Kuala Lumpur dan Darul al-Quran, Jabatan Kemajuan Islam Malaysia (JAKIM)", Latihan ilmiah Sarjana Muda, Akademik Pengajian Islam, Universiti Malaya.

Masahuri Sampe (2002). “Keberkesanan Penghafalan al-Quran: Satu Kajian Di Ma'ahad Tahfiz al-Quran al-Itqan" Latihan ilmiah Sarjana Muda, Akademik Pengajian Islam, Universiti Malaya.

Md Romzi Abdullah (1999). “Tahfiz alQuran dan Tarbiahnya Dalam Melahirkan Para Huffaz yang Berwibawa: Kajian Khusus di Madrasah al-Quran Kubang Bujuk, Kuala Terengganu”, Latihan ilmiah Sarjana Muda, Universiti Kebangsaan Malaysia.

Mohamad Marzuki Abdul Rahim (2008). dari pada tahun 2008 bertajuk: Pengajaran Mata Pelajaran Hafazan alQuran: Suatu Kajian Ma'ahad Tahfiz Zon Tengah”, Disertasi Sarjana, Fakulti Sains Kognitif dan Pembangunan Manusia, Universiti Pendidikan Sultan Idris. 
Muhaidi Haji Mustaffa (2010). "Hafazan alQuran dan Hubungannya Dengan Kecemerlangan Pelajar: Kajian di Maahad Tahfiz al-Quran wal Qiraat Pulai Chondong, Kelantan dari Tahun 1997-2007” Disertasi Sarjana Universiti Malaya.

Norkhairolizah binti Hamzah (2005). "Parantel Role In Promoting Children's Quranic Memorization", Disertasi Sarjana, Pusat Pendidikan dan Pembangunan Insan, Universiti Islam Antarabangsa.

Sedek Ariffin (2012). Kaedah menghafal alQur'an di Institusi Tahfiz al-Qur'an di Malaysia: Kajian perbandingan di antara kaedah Darul Quran, JAKIM dengan kaedah al-huffaz, Thesis Ph.D, Akademi Pengajian Islam, Universiti Malaya.

Syed Ahmad Tarmizi bin Syed Omar(2003).

Tahfiz al-Quran: Sejarah dan Perkembangannya, Seminar Kaedah Pengajaran dan Tahfiz al-Quran, Mei, KUIM.hlm.13

Abdul Aziz Abdul Rauf. (1994). Kiat Sukses Menjadi Hafidz Qur'an Da'iyah; Syarat Dengan Penanaman Motivasi, Penjelasan Teknis Dan Pemecahan Masalah. Jakarta: Insan Qur'ani Press.

Abdul Hafiz bin Haji Abdullah (Ketua Penyelidik). (2003). Penyelidikan
Jangka Pendek: Keberkesanan Kaedah Hafazan Di Pusat Tahfiz. Skudai: Research Management Centre Universiti Teknologi Malaysia.

Abu Najihat al-Hafiz. (2001). Panduan Bagi Hafiz-Hafizah \& Qari-Qari'ah. Selangor: Penerbitan Darul Iman Sdn. Bhd. Abu Shabah, Muhammad bin Muhammad. (1992). al-Madkhal li Dirasat al-Quran alKarim. Bayrut: Dar al-Jayl.

Abu Zar'ah, Abdul Rahman bin Muhammad. (2001). Hujjat al-Qiraat. Bayrut:Mu'assasat al-Risalah.

Afaf Abdul Ghafor Hameed. Dr., Adel M. Abdulaziz. Dr., Mohamed Abdullahi Nur.Dr., Muhammad Mustaqim Mohd Zarif. (2003). Isu Semasa Pengajian: Quran Dan Sunnah. Siri 1, Sidang Editorial, KUIM: Fakulti Pengajian Quran dan Sunnah.

al-Sharbini, Ibrahim Abd. al-Mu'an. (1995).

Qasd al-Sabil Ila al-Jinan Bi Bayan Kaif Tahfaz al-Quran. Mansurah: Maktabat al-Iman.

Abdul Mutalib bin Hussain. (2003). Pengajian Tahfizal-Quran: Satu Kajian di Ma'ahad Tahfiz al-Quran Wal Qiraat, Pulau Pinang. Fakulti Usuluddin Akademi Islam UM KL: Latihan Ilmiah Ijazah Sarjana Muda. 
Noor Hafizi Yusof - Kaedah Pintar Murojaah... Homepage: http://journal.umg.ac.id/index.php/tamaddun

Badarudin Taroji. (1998). Tahfiz Al-Quran Di Malaysia: Satu Tinjauan Mengenai Sistem Pentadbiran Dan Sistem Pembelajarannya, Tinjauan Khusus Di Lembah Klang. Bahagian Pengajian Syariah, Akademi Pengajian Islam, UM, KL: Latihan Ilmiah Ijazah Sarjana Muda.

Fauziah Mohd Noor. (1993). Penghafalan al-Quran Di kalangan Wanita: Satu Kajian di Maahad Tahfiz, Pusat Islam.
Fakulti Usuluddin Akademi Islam UM

KL: Latihan Ilmiah Ijazah Sarjana Muda.

Mohd Fazri Ahmad Murad. (1999). MetodeMetode Penghafalan al-Quran : Kajian Khusus di Maahad Tahfizal-Quran Wal Qiraat Negeri Sembilan, Maahad Ahmadi, Gemenceh, Negeri Sembilan. Universiti Malaya: Latihan Ilmiah Ijazah Sarjana Muda 
TAMADDUN: Jurnal Pendidikan dan Pemikiran Keagamaan

P-ISSN : 1693-3941; E-ISSN : 2722-2632 Vol. 21. No. 2 Juli 2020 